\title{
Water-Quality Comparison of the Gulf Coast Aquifer System and Carrizo-Wilcox Aquifer in Texas From National Water-Quality Assessment Project Principal Aquifer Surveys, 2013 and 2015
}

The U.S. Geological Survey's National Water-Quality Assessment (NAWQA) Project assessed the quality of groundwater in aquifers that are important sources of drinking water in the United States (DeSimone and others, 2014). One major aquifer in Texas that was assessed by NAWQA in 2013 is the coastal lowlands aquifer system, which is often referred to in Texas as the "Gulf Coast aquifer system" (fig. 1). The coastal lowlands aquifer system supplies water for millions of people; Maupin and Arnold (2010, p. 5) reported that self-supplied (private) well withdrawals in 2005 from this aquifer system were the sixth largest among all major aquifer systems in the Nation. A major aquifer in Texas that was assessed by NAWQA in 2015 is the Texas coastal uplands aquifer system; the Carrizo-Wilcox aquifer is one of several aquifers that compose this aquifer system in Texas. The rocks composing the Texas coastal uplands aquifer system extend east from Texas as part of the Mississippi embayment aquifer system and underlie areas of several States (fig. 1) (Renken, 1998). The Texas coastal uplands aquifer system and Mississippi embayment aquifer system are often collectively referred to as the "Mississippi embayment-Texas coastal uplands aquifer system" (for example, Kingsbury and others, 2014). Self-supplied withdrawals from the Mississippi embayment-Texas coastal uplands aquifer system in
2005 were the eighth largest among all major aquifer systems in the Nation (Maupin and Arnold, 2010). The coastal lowlands aquifer system and Mississippi embayment-Texas coastal uplands aquifer system were assessed as part of the NAWQA Principal Aquifer Surveys (PAS), which were designed to evaluate constituent concentrations in water samples obtained from domestic and public-supply wells prior to any treatment (DeSimone and others, 2014). PAS assessments like these allow for the comparison of water-quality concentrations in untreated groundwater using preestablished benchmarks for the protection of human health and for aesthetic qualities such as taste, color, and odor. The use of preestablished benchmarks can provide a basis for comparison of groundwater quality among principal aquifers (Norman and others, 2018).

The Gulf Coast aquifer system in Texas consists of a fluvial-deltaic wedge of discontinuous beds of sand, silt, and clay sediments deposited in bands that parallel the Gulf of Mexico coastline and range in age from Miocene to Holocene (Ryder, 1996). This wedge of unconsolidated to poorly consolidated sediments increases in thickness and depth toward the gulf (Ryder, 1996; Oden and Szabo, 2015). The Gulf Coast aquifer system stratigraphically consists of (from youngest to oldest)

$103^{\circ}$

$96^{\circ}$

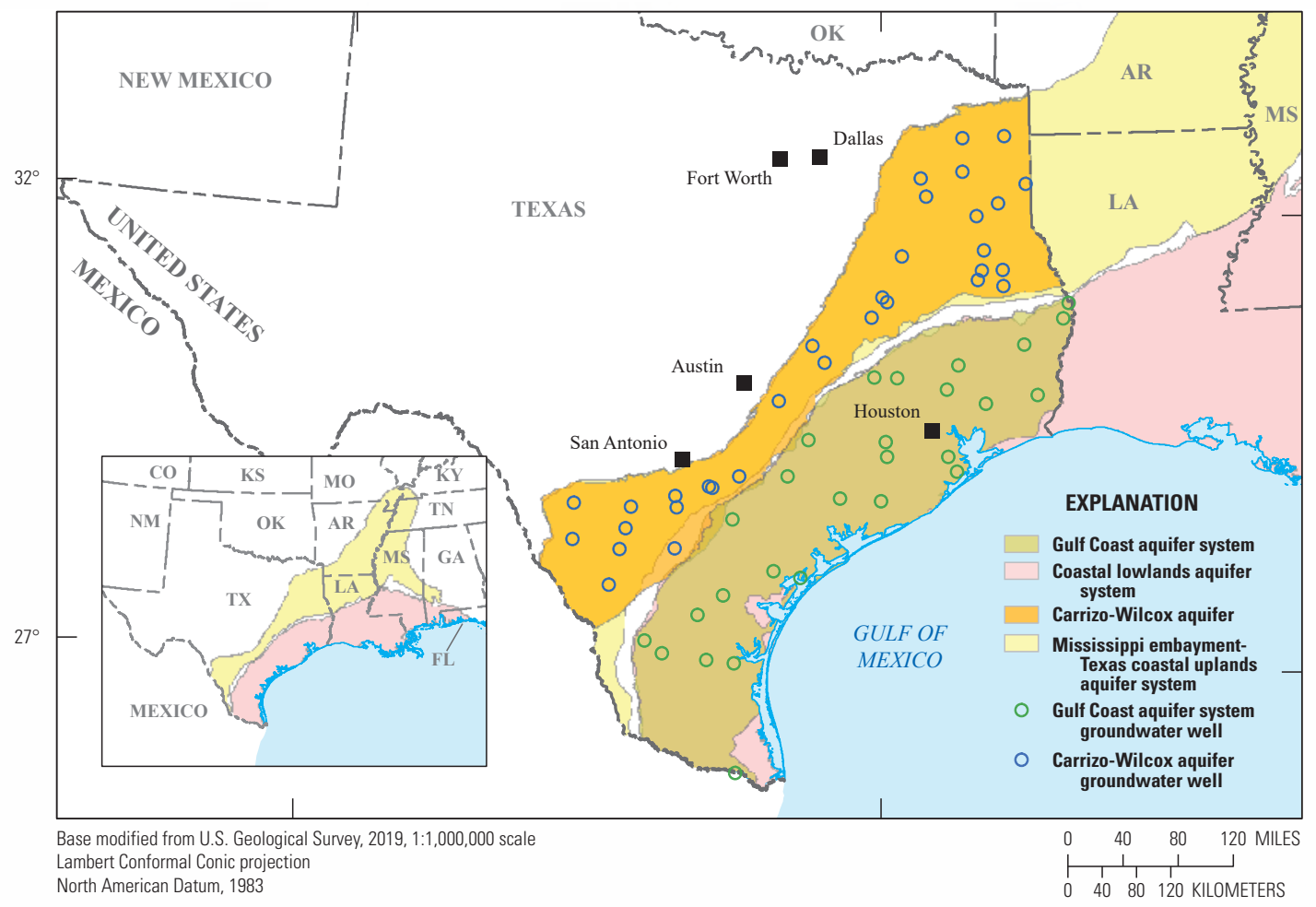

Figure 1. Principal Aquifer Survey groundwater well networks sampled in the Gulf Coast aquifer system and Carrizo-Wilcox aquifer in Texas in 2013 and 2015, respectively. 
the Chicot aquifer, Evangeline aquifer, Burkeville confining unit, Jasper aquifer, and Catahoula Sandstone (Oden, 2011). The Chicot and Evangeline aquifers historically were the primary sources of municipal supply water for the City of Houston; currently (2019) these aquifers provide only 14 percent of the source water for municipal supply in Houston (Oden and Szabo, 2015; City of Houston, 2019). The Carrizo-Wilcox aquifer consists mostly of sand that is locally interbedded with gravel, silt, clay, and lignite. Stratigraphically between the Gulf Coast aquifer system and the underlying (older) Carrizo-Wilcox aquifer is a series of minor aquifers (Yegua-Jackson, Sparta, and Queen City aquifers) that supply water to numerous cities and for agricultural purposes in a large part of Texas (George and others, 2011).

\section{Overview of Water-Quality Sampling and Benchmarks for Evaluating Groundwater Quality}

The public-supply well networks completed in the Gulf Coast aquifer system and Carrizo-Wilcox aquifer were sampled as part of the coastal lowlands aquifer system PAS and the Mississippi embayment-Texas coastal uplands aquifer system PAS in 2013 and 2015, respectively, to assess groundwater quality in parts of these aquifers deeper than those tapped by domestic wells. Samples were analyzed for basic water-quality properties (such as dissolved oxygen, $\mathrm{pH}$, specific conductance, temperature, and turbidity), major ions, nutrients, organic carbon, trace elements, select age-dating tracers, radionuclides, an extensive suite of pesticides, volatile organic compounds (VOCs), pharmaceuticals, and hormones. Water-quality results were compared to available benchmarks established for drinking-water quality or humanhealth concerns (fig. 2). Comparisons to preestablished benchmarks for drinking water provide context for evaluating the quality of untreated groundwater; the quality of finished (treated) drinking water often differs from the quality of untreated water (Norman and others, 2018). The water-quality analyses included many constituents that are generally not included as part of regulatory compliance monitoring. Some constituents that are useful for determining the sources and movement of groundwater were measured at concentrations lower than human-health benchmarks.

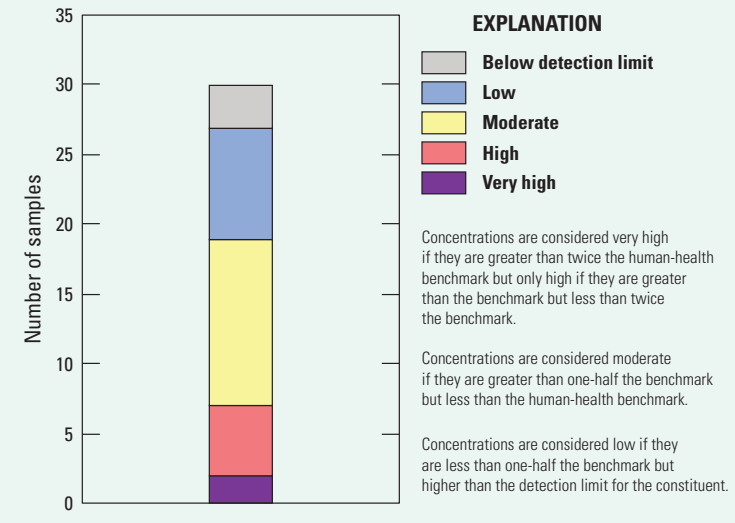

Figure 2. Example graph for concentrations compared to human-health benchmarks.

\section{Water-Quality Results for the Gulf Coast Aquifer System and Carrizo-Wilcox Aquifer}

Groundwater samples from public-supply wells completed in the Gulf Coast aquifer system and Carrizo-Wilcox aquifer were analyzed for inorganic constituents (such as dissolved solids, chloride, nutrients, and trace elements), radionuclides (such as gross alpha and beta activity and radon-222), and organic compounds (DeSimone and others, 2014). Many inorganic constituents are naturally present in groundwater. The concentrations of some inorganic constituents (such as dissolved solids and chloride) can be affected by natural processes and by human activities and can affect the aesthetic properties of water or can create nuisance problems, such as staining and scaling. The benchmarks used for dissolved solids and chloride are nonregulatory secondary maximum contaminant levels established for drinking water (Norman and others, 2018). Dissolved-solids concentration is a measure of the salinity of the groundwater based primarily on the concentrations of ions (such as chloride) and can affect aesthetic properties such as taste (fig. 3). All water naturally contains dissolved solids from weathering and dissolution of minerals in rocks and sediments, but some of the dissolved solids in water can result from human activities, such as fertilizer applications to land surface (Hem, 1985). Elevated dissolved-solids concentrations in groundwater may reflect longer residence times from deeper wells (fig. 3) (Kingsbury and others, 2014; Oden and Szabo, 2015).
$\boldsymbol{A}$

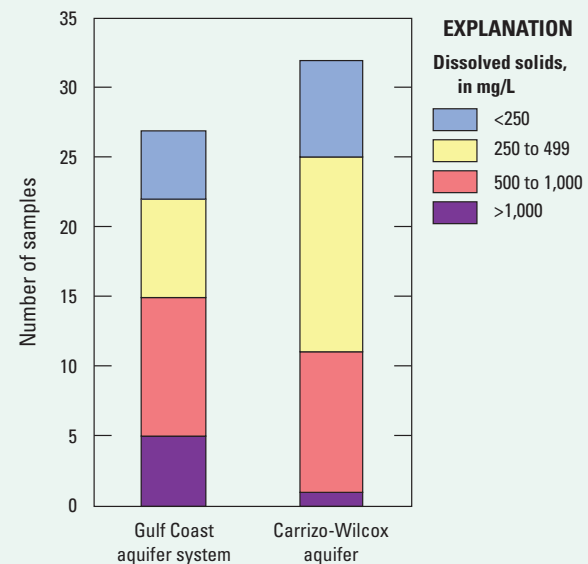

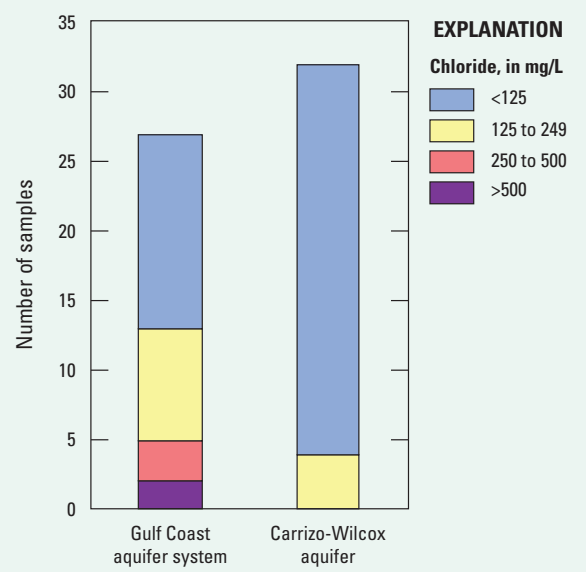

C

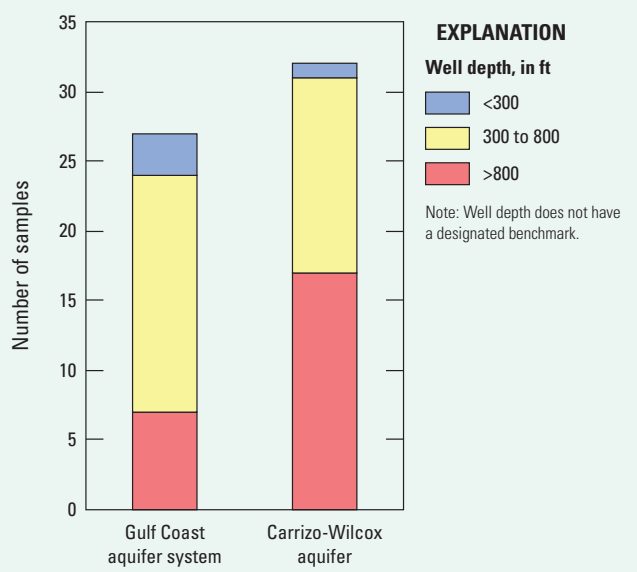

Figure 3. $A$, Dissolved-solids and $B$, chloride concentrations in milligrams per liter (mg/L) and $C$, well depth in feet (ft) for groundwater sampled in the Gulf Coast aquifer system and the Carrizo-Wilcox aquifer in Texas. 


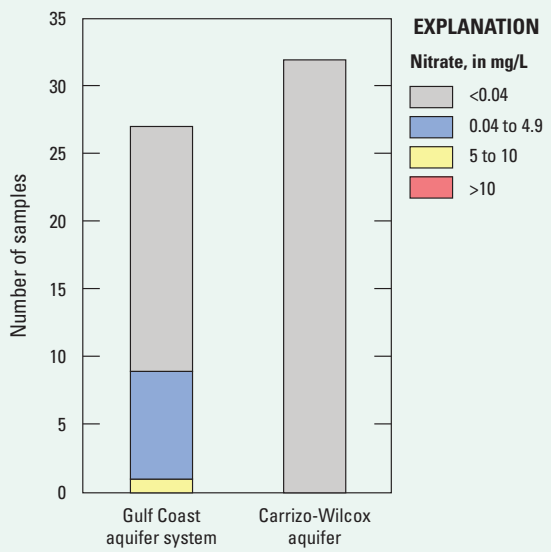

$B$

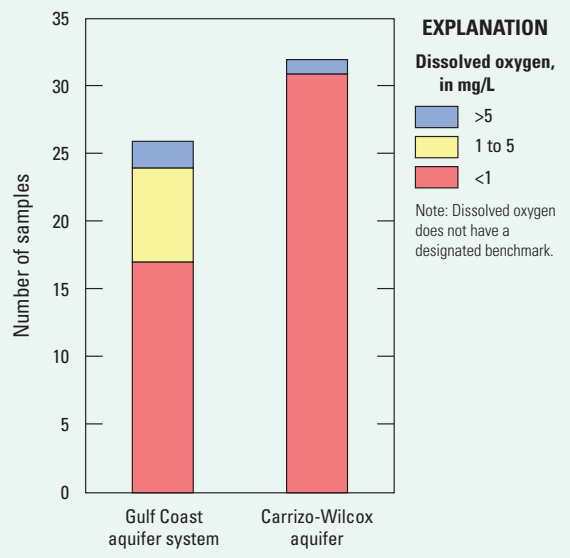

Figure 4. $\quad A$, Nitrate and $B$, dissolved oxygen concentrations in milligrams per liter ( $\mathrm{mg} / \mathrm{L}$ ) for groundwater sampled in the Gulf Coast aquifer system and the Carrizo-Wilcox aquifer in Texas.

Nutrients

Nutrients, such as nitrate, nitrite, and phosphorus, are naturally present at low concentrations in groundwater (less than one-half of human-health benchmarks); moderate or high concentrations (relative to human-health benchmarks) generally result from human activities (DeSimone and others, 2014). Samples in the PAS studies were analyzed for five nutrients, of which two (nitrate and nitrite) have human-health benchmarks (Norman and others, 2018). Common sources of nutrients, aside from soils, include fertilizer applied to crops and landscaping, seepage from septic systems, and human and animal waste (Hem, 1985). Analysis results for nitrogen in groundwater included nitrate plus nitrite concentrations. Because most of the nitrite concentrations in the groundwater samples were below detection limits ( 0.04 milligrams per liter), most of the nitrogen occurs as nitrate in the Gulf Coast aquifer system and Carrizo-Wilcox aquifer and may be related to dissolved oxygen concentrations in groundwater (fig. 4) (Arnold and others, 2016, 2017, 2018).

\section{Trace Elements}

Trace elements, such as arsenic and manganese, are naturally present in the minerals of rocks, soils, and sediments and in the water that interacts with those materials, although the concentrations of some trace elements can be affected by human activities (Hem, 1985). Samples in the PAS studies were analyzed for 34 trace elements, of which 19 have human-health benchmarks (Norman and others, 2018). Arsenic and manganese were the only trace elements detected at concentrations that exceeded established human-health benchmarks (fig. 5)

(Arnold and others, 2016, 2017, 2018).
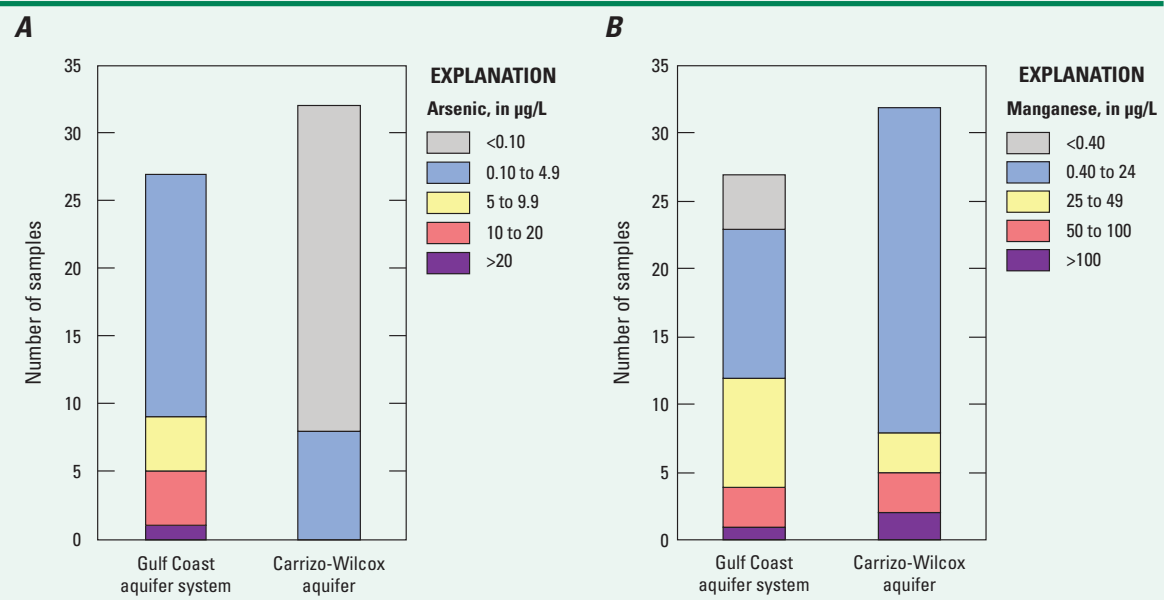

Figure 5. $\quad A$, Arsenic and $B$, manganese concentrations in micrograms per liter ( $\mu \mathrm{g} / \mathrm{L})$ for groundwater sampled in the Gulf Coast aquifer system and the Carrizo-Wilcox aquifer in Texas.

\section{Radionuclides}

Radioactivity is the release of energy or energetic particles during the spontaneous decay of unstable atoms (radionuclides). Humans are continuously exposed to small amounts of natural radioactivity. Most of the radioactivity in groundwater comes from the decay of isotopes of uranium and thorium that are naturally

A

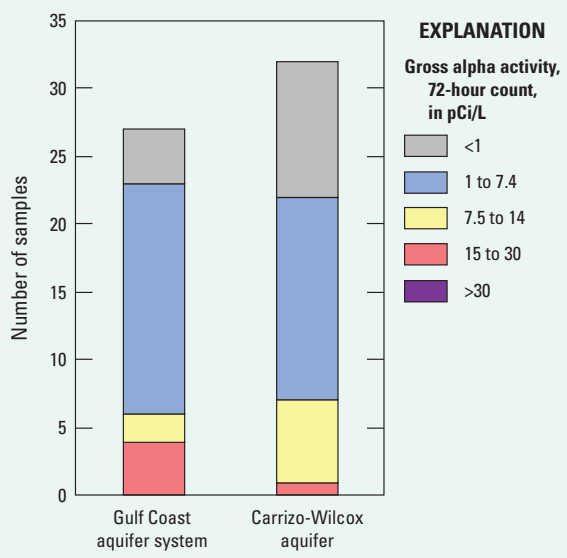

B

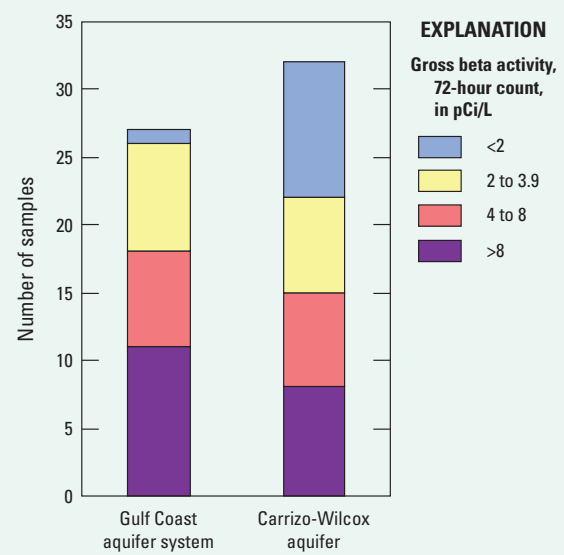

present in minerals in aquifer materials (Hem, 1985). Samples in the PAS studies were analyzed for eight radionuclides, four of which have human-health benchmarks (Norman and others, 2018). Gross alpha activity, gross beta activity, and radon-222 were the only radionuclides detected at concentrations that exceeded established human-health benchmarks (fig. 6) (Arnold and others, 2016, 2017, 2018).

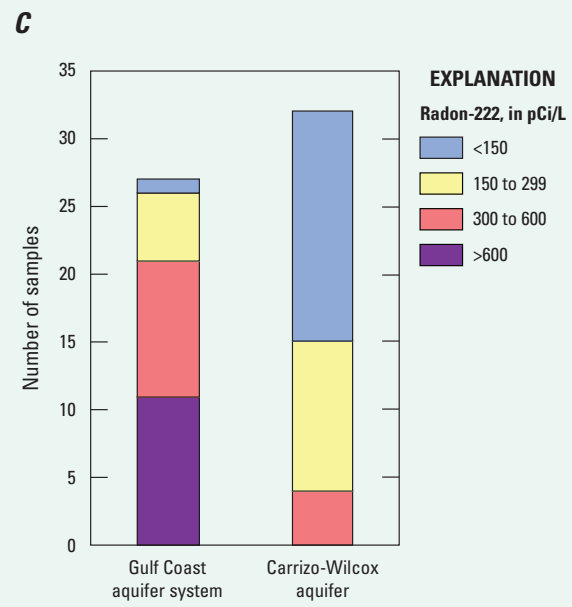

Figure 6. $A$, Gross alpha and $B$, gross beta activity and $C$, radon-222 concentrations in picocuries per liter (pCi/L) for groundwater sampled in the Gulf Coast aquifer system and the Carrizo-Wilcox aquifer in Texas. 


\section{Organic Compounds}

Organic compounds derived from human activities are found in household, business, industrial, and agricultural products and can enter the environment through normal usage, spills, or improper disposal. Many organic compounds are commonly detected in surface water and bed sediments in urban, suburban, and agricultural areas (Battaglin and others, 2018). Organic compounds that were analyzed in the PAS studies included VOCs, pesticides, pharmaceuticals, and hormones (DeSimone and others, 2014). Many of these organic compounds do not have established human-health benchmarks, but none of the concentrations measured in groundwater samples collected from wells completed in the Gulf Coast aquifer system or Carrizo-Wilcox aquifer exceeded any established humanhealth benchmarks for organic compounds (fig. 7) (Norman and others, 2018; Arnold and others, 2016, 2017, 2018).

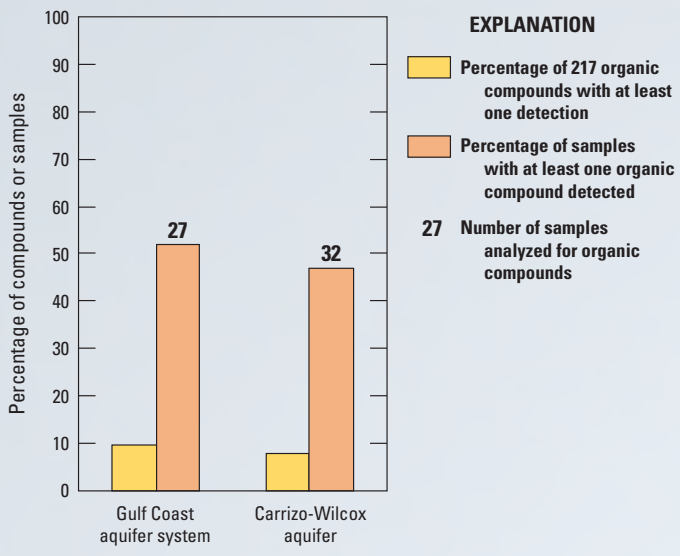

Figure 7. Percentage of organic compounds detected and percentage of samples with organic compound detections in groundwater sampled in the Gulf Coast aquifer system and the CarrizoWilcox aquifer in Texas.

\section{References Cited}

Arnold, T.L., Bexfield, L.M., Musgrove, M., Lindsey, B.D., Stackelberg, P.E., Barlow, J.R., DeSimone, L.A., Kulongoski, J.T., Kingsbury, J.A., Ayotte, J.D., Fleming, B.J., and Belitz, K., 2017, Groundwater-quality data from the National Water-Quality Assessment Project, January through December 2014 and select quality-control data from May 2012 through December 2014: U.S. Geological Survey Data Series 1063, 83 p., accessed October 21, 2019, at https://doi.org/10.3133/ds 1063.

Arnold, T.L., Bexfield, L.M., Musgrove, M., Stackelberg, P.E., Lindsey, B.D., Kingsbury, J.A., Kulongoski, J.T., and Belitz, K., 2018, Groundwater-quality and select quality-control data from the National Water-Quality Assessment Project, January through December 2015, and previously unpublished data from 2013 to 2014: U.S. Geological Survey Data Series 1087, 68 p., accessed October 21, 2019, at https://doi.org/10.3133/ds1087.

Arnold, T.L., DeSimone, L.A., Bexfield, L.M., Lindsey, B.D., Barlow, J.R., Kulongoski, J.T., Musgrove, M., Kingsbury, J.A., and Belitz, K., 2016, Groundwater quality data from the National Water-Quality Assessment Project, May 2012 through December 2013: U.S. Geological Survey Data Series 997, 56 p., accessed October 21, 2019, at http://dx.doi.org/10.3133/ ds997.

Battaglin, W.A., Bradley, P.M., Iwanowicz, L., Journey, C.A., Welsh, H.L., and Blazer, V.S., 2018, Pharmaceuticals, hormones, pesticides, and other bioactive contaminants in water, sediment, and tissue from Rocky Mountain National Park, 2012-2013: Science of the Total Environment, v. 643, p. $651-673$.

City of Houston, 2019, Drinking water operations: City of Houston, accessed September 30, 2019, at https://www.publicworks.houstontx.gov/pud/ drinkingwater.html.

DeSimone, L.A., McMahon, P.B., and Rosen, M.R., 2014, The quality of our Nation's waters-Water quality in principal aquifers of the United States, 1991-2010: U.S. Geological Survey Circular 1360, 151 p., accessed October 21, 2019, at http://dx.doi.org/10.3133/cir1360.

George, P.G., Mace, R.E., and Petrossian, R., 2011, Aquifers of Texas: Texas Water Development Board Report 380, 172 p.

Hem, J.D., 1985, Study and interpretation of the chemical characteristics of natural water (3d ed.): U.S. Geological Survey Water-Supply Paper 2254, $263 \mathrm{p}$.

Kingsbury, J.A., Barlow, J.R.B., Katz, B.G., Welch, H.L., Tollett, R.W., and Fahlquist, L.S., 2014, The quality of our Nation's waters-Water quality in the Mississippi embayment-Texas coastal uplands aquifer system and Mississippi River Valley alluvial aquifer, south-central United States, 1994 2008: U.S. Geological Survey Circular 1356, 72 p., accessed October 21, 2019, at http://dx.doi.org/10.3133/cir1356.
Maupin, M.A., and Arnold, T.L., 2010, Estimates for self-supplied domestic withdrawals and population served for selected principal aquifers, calendar year 2005: U.S. Geological Survey Open-File Report 2010-1223, 10 p., accessed October 21, 2019, at https://doi.org/10.3133/ ofr20101223.

Norman, J.E., Toccalino, P.L., and Morman, S.A., 2018, Health-Based Screening Levels for evaluating water-quality data ( 2 d ed.): U.S. Geological Survey database, accessed January 23, 2020, at https://water. usgs.gov/nawqa/HBSL, doi:10.5066/F71C1TWP.

Oden, J.H., and Szabo, Z., 2015, Arsenic and radionuclide occurrence and relation to geochemistry in groundwater of the Gulf Coast aquifer system in Houston, Texas, 2007-11: U.S. Geological Survey Scientific Investigations Report 2015-5071, 105 p., 4 apps., accessed October 21, 2019, at http://dx.doi.org/10.3133/sir20155071.

Oden, T.D., 2011, Groundwater environmental tracer data collected from the Chicot, Evangeline, and Jasper aquifers in Montgomery County and adjacent counties, Texas, 2008: U.S. Geological Survey Data Series 580, 37 p., accessed September 30, 2019, at https://pubs.usgs.gov/ds/580/.

Renken, R.A., 1998, Ground water atlas of the United States-Arkansas, Louisiana, Mississippi: U.S. Geological Survey Hydrologic Atlas 730-F, accessed October 21, 2019, at https://pubs.usgs.gov/ha/ha730/ch_f $/$ index. html.

Ryder, P.D., 1996, Ground water atlas of the United States-Oklahoma, Texas: U.S. Geological Survey Hydrologic Atlas 730-E, accessed October 21, 2019, at http://pubs.usgs.gov/ha/ha730/ch_e/index.html.

\section{By Patricia B. Ging}

\section{For more information about NAWOA activities in Texas, please contact}

Director, Oklahoma-Texas Water Science Center

U.S. Geological Survey

1505 Ferguson Lane

Austin, TX 78754

gs-w-txpublicinfo@usgs.gov

or visit https://www.usgs.gov/centers/tx-water 